\title{
Effect of Bt Transgene on AM Fungi Infection and Yield Attributes of Cotton (Gossypium hirsutum L.)
}

\author{
Kasturikasen Beura ${ }^{*}$, Amit Kumar Pradhan ${ }^{1}$, Amitava Rakshit ${ }^{2}$ and Mahendra Singh ${ }^{1}$ \\ ${ }^{*}$ Dept. of Soil Science and Agricultural Chemistry, Bihar Agricultural University, Sabour, Bihar (813 210), India \\ ${ }^{*}$ Presently Dept. of Soil Science and Agricultural Chemistry, Bihar Agricultural University, Sabour, \\ Bhagalpur, Bihar (813 210), India \\ ${ }^{2}$ Dept. of Soil Science and Agricultural Chemistry, BHU, Varanasi, U.P. (813 210), India
}

\section{Article History}

Manuscript No. AR1364

Received in $30^{\text {th }}$ March, 2015

Received in revised form $29^{\text {th }}$ July, 2015

Accepted in final form $4^{\text {th }}$ August, 2015

\section{Correspondence to}

"E-mail: beura.kasturi88@gmail.com

\section{Keywords}

Bt cotton, AM fungi, yield attributes, soil order

\begin{abstract}
A pot experiment was carried out in 2010 during wet season (July to December) at the Institute of Agricultural Sciences, Banaras Hindu University to evaluate the extent of root infection by AM (Arbuscular Mycorrhiza) fungi and yield attributing characteristics of cotton under both Bt (Bacillus thuringiensis) and non-Bt systems under varied soil types. It included three different soil orders i.e. Entisol, Inceptisol and Alfisol. Bt cotton (cv. NCS-138) and its non-transgenic isoline (cv. NCS-138) were grown until maturity. From the results it was evident that among the three different soils, red soil exhibited higher root infection in comparison to alluvial and black soil. Per cent root infection decreased significantly to the extent of $10-13 \%$ in Bt crop as compared to non-Bt counterpart and 9.5-15\% during the three growth stages. During the intermediate stages of crop growth, there were significant differences in growth parameters and yield attributes between $\mathrm{Bt}$ and the non-Bt isoline. It was also observed that the alluvial soil produced higher shoot biomass compared to black and red soil during initial stages of crop growth. But during the intermediate stages of crop cycle, the growth picked up in black soil. In the final stage, alluvial soil produced higher biomass as compared to the black and red soil. At the same time, Bt-cotton plants showed comparatively more root length than non-Bt crop over the entire crop growth stages.
\end{abstract}

\section{Introduction}

Cotton (Gossypium hirsutum L.) is the most important fiber crop in India which plays a key role in economic and social development. India is a leading cotton producing country, and the area under Bt cotton cultivation was $11 \mathrm{~m}$ ha during 2013 (James, 2013) but until now there is hardly any information (especially quantitative data) generated from India about the impact of Bt cotton on soil microbiological processes (Beura and Rakshit, 2011). Although there is large-scale adoption of Bt-cotton by the farmers because of immediate financial gain, there is concern that transgenic Bt-crops (which release Bt-toxins into the environment) affect yield and microbial parameters in the agro-ecosystem. These toxins are produced in every major part of Bt-cotton plants (Dong and Li, 2007). Thus transgenic plants have the potential to modify the rhizosphere chemistry by altering plant residue quality (Dunsfield and Germida, 2004; Motavalli et al., 2004; O'callaghan et al.,
2005). Any change in the quality of rhizosphere exudates can modify the soil biota composition as well as their activity (Stotzky, 2004; Patra et al., 2006) and may produce changes in microflora and microfauna (Wei et al., 2006; Griffiths et al., 2006). Bt cotton may differ from its non-Bt counterpart in some agronomic and physiological traits, but lint yield remains unchanged due to the manipulation of boll numbers, boll weight and lint percentage under insect-free condition (Dong et al., 2006); Blanche et al. (2006) found that cultivars containing the Bollgard gene (the gene for the insecticidal protein from Bacillus thuringiensis spp. kurstaki; Monsanto Co.) yielded more than the conventional cultivars under optimal growth condition. With the above backdrop, our research was designed to evaluate yield attributes of cotton under both $\mathrm{Bt}$ and non-Bt systems under different soil types.

\section{Materials and Methods}

A pot experiment was carried out in 2010 during wet season 
(July to December) with three different soil types at the Institute of Agricultural sciences, Banaras Hindu University, Varanasi $\left(25^{\circ} 19^{\prime} 60 \mathrm{~N}\right.$ Latitude and $83^{\circ} 0^{\prime} 0$ E Longitude). Bt cotton (cv. NCS-138) and its non-transgenic isoline (cv. NCS138) were grown until maturity. A no-crop reference pot was maintained with three replications for all the three soil types. The experiment was laid out in a factorial complete randomized block design with three replications.

\subsection{Analysis of soil samples}

Surface samples $(0-15 \mathrm{~cm})$ from cultivated soils of three orders i.e. Entisol, Inceptisol and Alfisol were collected from different geographical locations in the Varanasi and Mirzapur districts of Uttar Pradesh, India. The air-dried soils samples used in the pot experiment were ground and sieved through a $2 \mathrm{~mm}$ sieve, and then stored in plastic bags. An initial soil sample was analyzed for different physico-chemical parameters following the standard protocol. The $\mathrm{pH}$ and electrical conductivity of the soil was determined by Glass electrode $\mathrm{pH}$ meter and Conductivity meter (Jackson, 1973) respectively. The textural class was determined by (Bouyoucos, 1962). Rhizospheric soil samples were analyzed for mineral-N by (Subbiah and Asija, 1956), available P by (Olsen et al., 1954), available-K by (Hanway and Heidel, 1952), organic carbon by (Walkley and Black, 1934) and available cationic micronutrients by (Lindsay and Norvell, 1978) after the harvesting of cotton crop.

Root infection was assessed on a representative root sample taken from each plot at harvest. At harvest roots of $15 \mathrm{~cm}$ were taken from plants evenly distributed in each plot. Mycorrhiza infection of each plant was determined by estimating the percent of root segments colonised with AM with the method as described by (Bierman and Linderman, 1981).

Percent root infection was obtained as follows:

$\%$ Root infection $=\frac{\begin{array}{c}\text { Number of root segments } \\ \text { infected with AM }\end{array}}{\text { Total number of segments }} \times 100$

The root length was determined by using conventional technique while the shoot and root biomass was determined after drying the roots for $24 \mathrm{hrs}$ at $60-70{ }^{\circ} \mathrm{C}$ in an oven. At maturity, the total number of bolls and the boll size (weight) were recorded.

\section{Results and Discussion}

\subsection{AM fungi infection in roots of cotton plant}

The data in the Table 2 revealed that Bt-cotton affected AM fungi during the complete life cycle. Per cent root infection decreased significantly to the extent of $10-13 \%$ in Bt crop as compared to non-Bt counterpart and $9.5-15 \%$ during the three growth stages. Although AM colonization of cotton normally progresses quickly during the first few weeks of growth reaching a plateau at 100 DAS with $45-60 \%$ of root length colonized by arsbucules. The pattern of development of mycorrhizal colonization in our assessment was a typical sigmoid pattern of logistic growth over 20 weeks of assessment. Among the three soils, red soil exhibited higher root infection as compared to alluvial and black soil, which can be explained by the differences in available $\mathrm{P}$ value. AM fungi colonized both the $\mathrm{Bt}$ and non-Bt cotton cultivars equally, providing firm evidence that both the $\mathrm{Bt}$ and non-Bt cotton cultivars were equally capable of establishing mycorrhizal symbiosis (Glandorf et al., 1997). The lack of differences in colonization between $\mathrm{Bt}$ and conventional cotton that we observed corroborates with that reported for GM and conventional soybean (Powell et al., 2007) but is in contrast to reports of differential mycorrhizal colonization of GM corn (Turrini et al., 2004; Castaldini et al., 2005).

\subsection{Yield attributes of cotton}

The pot experiment also revealed that Bt-cotton was able to resist insect infestation resulting in good boll retention and higher yields compared to non-Bt cotton crop. Thus, less chemical spray was required to control insect attack in Btcotton crop. Seed cotton yield in Bt-cotton crop ranged from 26.85 to $83.92 \mathrm{~g} \mathrm{pot}^{-1}$ in alluvial soil while $13.6-46.7 \mathrm{~g} \mathrm{pot}^{-1}$ in red soil. So, in the present study, an average yield increase

\begin{tabular}{lccc}
\hline \multicolumn{4}{c}{ Table 1: Physico-chemical characterization of the soils } \\
\hline Parameters & \multicolumn{3}{c}{ Values } \\
\hline Physical & Red & Black & Alluvial \\
& soil & soil & soil \\
\hline Bulk density $\left(\mathrm{Mg} \mathrm{m}^{-3}\right)$ & 1.38 & 1.51 & 1.43 \\
Particle density $\left(\mathrm{Mg} \mathrm{m}^{-3}\right)$ & 2.51 & 2.60 & 2.56 \\
Water holding capacity (\%) & 39.4 & 45.40 & 41.6 \\
Sand (\%) & 46.00 & 11.7 & 48.78 \\
Silt $(\%)$ & 32.85 & 52.7 & 30.48 \\
Clay $(\%)$ & 21.15 & 35.6 & 20.44 \\
Soil texture & Silty clay & Clay- & Sandy \\
& loam & ey & $10 a m$ \\
Electro-chemical and chemical & & & \\
\hline pH ${ }_{\text {w }}(1: 2.5)$ & 6.3 & 7.5 & 7.1 \\
Electrical conductivity $\left(\mathrm{d} \mathrm{Sm}^{-1}\right)$ & 0.32 & 0.61 & 0.45 \\
CEC $\left\{\right.$ Cmol $\left.(\mathrm{p}+) \mathrm{kg}^{-1}\right\}$ & 18.25 & 31.85 & 19.55 \\
Organic carbon $(\%)$ & 0.34 & 0.42 & 0.38 \\
Available nitrogen $\left(\mathrm{kg} \mathrm{ha}^{-1}\right)$ & 176 & 238 & 232 \\
Available phosphorus $\left(\mathrm{kg} \mathrm{ha}^{-1}\right)$ & 8 & 14 & 18 \\
Available potassium $\left(\mathrm{kg} \mathrm{ha}^{-1}\right)$ & 110 & 165 & 148 \\
Zn (ppm) & 3.64 & 2.7 & 2.86 \\
Ca (meq 100g-1) & 3.1 & 32.5 & 10.2 \\
\hline
\end{tabular}


of $30.6 \%$ in Bt-cotton crop compared to non Bt-cotton crop was observed due to effective control of insects. The increase seed cotton yield in this cultivar may be attributed to better fruiting efficiency, efficient source-sink relationship, in-built resistance to bollworms, more number of picked bolls plant ${ }^{-1}$ and finally higher seed cotton yield. Such yield advantage of Bt-cotton hybrids over non-Bt cotton hybrids were also observed by (Halemani et al., 2004; Hallikeri et al., 2004; Srinivasulu et al., 2006).

\begin{tabular}{|c|c|c|c|c|c|}
\hline \multirow[t]{2}{*}{ DAS } & \multirow[t]{2}{*}{ Cultivar (C) } & \multicolumn{3}{|c|}{ Soil types (S) } & \multirow[b]{2}{*}{ Mean } \\
\hline & & $\mathrm{S}_{1}$ & $\mathrm{~S}_{2}$ & $\mathrm{~S}_{3}$ & \\
\hline \multirow[t]{5}{*}{50} & Non-Bt $\left(\mathrm{V}_{1}\right)$ & 35.3 & 19.66 & 21.33 & 24.43 \\
\hline & $\mathrm{Bt}\left(\mathrm{V}_{2}\right)$ & 31 & 16.33 & 18.33 & 21.88 \\
\hline & Mean & 33.15 & 17.99 & 19.83 & \\
\hline & $\operatorname{SEm} \pm$ & \multirow{2}{*}{\multicolumn{4}{|c|}{$\begin{array}{c}\mathrm{C}=0.32, \mathrm{~S}=0.393, \mathrm{C} \times \mathrm{S}=0.556 \\
\mathrm{C}=1.01, \mathrm{~S}=1.24, \mathrm{C} \times \mathrm{S}=1.754\end{array}$}} \\
\hline & $\mathrm{CD}(p=0.05)$ & & & & \\
\hline \multirow[t]{5}{*}{100} & Non-Bt $\left(\mathrm{V}_{1}\right)$ & 60.3 & 48.33 & 56 & 54.87 \\
\hline & $\mathrm{Bt}\left(\mathrm{V}_{2}\right)$ & 54.33 & 44.66 & 51 & 49.99 \\
\hline & Mean & 57.31 & 46.49 & 53.5 & \\
\hline & $\mathrm{SEm} \pm$ & \multirow{2}{*}{\multicolumn{4}{|c|}{$\begin{array}{c}\mathrm{C}=0.475, \mathrm{~S}=0.58, \mathrm{C} \times \mathrm{S}=0.826 \\
\mathrm{C}=1.50, \mathrm{~S}=1.82, \mathrm{C} \times \mathrm{S}=2.6\end{array}$}} \\
\hline & $\mathrm{CD}(p=0.05)$ & & & & \\
\hline \multirow[t]{5}{*}{150} & Non-Bt $\left(\mathrm{V}_{1}\right)$ & 24.66 & 20.00 & 20.66 & 21.77 \\
\hline & $\operatorname{Bt}\left(\mathrm{V}_{2}\right)$ & 22.66 & 17.33 & 17.66 & 19.21 \\
\hline & Mean & 23.66 & 18.66 & 19.16 & \\
\hline & $\mathrm{SEm} \pm$ & \multirow{2}{*}{\multicolumn{4}{|c|}{$\mathrm{C}=0.173, \mathrm{~S}=0.212, \mathrm{C} \times \mathrm{S}=0.301$}} \\
\hline & $\mathrm{CD}(p=0.05)$ & & & & \\
\hline
\end{tabular}

$\left(\mathrm{S}_{1}\right.$ : Red soil; $\mathrm{S}_{2}$ : Black soil; $\mathrm{S}_{3}$ : Alluvial soil; $\mathrm{V}_{1}$ : Non-Bt cultivar; $\mathrm{V}_{2}$ : Bt cultivar; $\mathrm{V}_{3}$ : No crop; DAS: Days after sowing).

\subsection{Root characteristics of cotton plant}

Root characteristics are the important factors that influence the rhizosphere biochemistry and the transformation of nutrients. One of the major avenues for release of Bt-toxin into the soil is through root exudates of Bt-crops. Similar trends were also documented by Benedict and Ring (2004). From the data in Table 4 it is evident that alluvial soil produced higher shoot biomass compared to black and red soil during initial stages of crop growth. But during the intermediate stages of life cycle, the growth picked up in black soil. In the final stage, alluvial soil produced higher biomass compared to black and red soil. Root biomass did not exhibit significant difference among Bt and non-Bt crop (Table 5). At the initial growth stage (50 DAS), root volume was similar for both the crops, but during later stage (100 and 150 DAS) root volume showed significant differences among Bt and non-Bt cultivars. Root length did not vary much between $\mathrm{Bt}$ and non-Bt-cotton crops at initial growth stages (50 DAS). While at $100 \mathrm{DAS}$, there were significant differences in root length among $\mathrm{Bt}$ and the non-Bt isoline. In general Bt-cotton plants showed comparatively more root length than non-Bt crop over the entire crop growth stages. Among the different soil types, alluvial soil produced higher root volume and length compared to black and red soil. The results are in close proximity with the result reported by other investigators (Hebbar et al., 2007 and Prakash et al., 2008).

Plant height did not vary much between Bt and non-Bt cotton crops at initial stage of crop growth (50 DAS). But during the intermediate stages, plant height varied significantly among $\mathrm{Bt}$ and non-Bt isoline (Table 5). It is further evident that alluvial soil produced higher shoot biomass compared to black and red soil during initial stages. But during the intermediate stages of life cycle, the growth picked up in black soil. In the final

\begin{tabular}{|c|c|c|c|c|c|c|c|c|c|c|c|c|}
\hline & \multicolumn{6}{|c|}{ No. of bolls plant ${ }^{-1}$} & \multicolumn{6}{|c|}{ Bolls weight $\left(\mathrm{g} \mathrm{plant}^{-1}\right)$} \\
\hline & \multicolumn{3}{|c|}{100 DAS } & \multicolumn{3}{|c|}{$150 \mathrm{DAS}$} & \multicolumn{3}{|c|}{100 DAS } & \multicolumn{3}{|c|}{150 DAS } \\
\hline & $\mathrm{V}_{1}$ & $\mathrm{~V}_{2}$ & Mean & $\mathrm{V}_{1}$ & $\mathrm{~V}_{2}$ & Mean & $\mathrm{V}_{1}$ & $\mathrm{~V}_{2}$ & Mean & $\mathrm{V}_{1}$ & $\mathrm{~V}_{2}$ & Mean \\
\hline $\mathrm{S}_{1}$ & 3 & 5 & 4 & 9 & 12 & 10.5 & 10.46 & 16.74 & 13.6 & 38.3 & 55.1 & 46.7 \\
\hline $\mathrm{S}_{2}$ & 7 & 8 & 7.5 & 18 & 21 & 19.5 & 22.66 & 28.26 & 25.43 & 74.61 & 97.02 & 85.81 \\
\hline $\mathrm{S}_{3}$ & 7 & 9 & 8 & 16 & 19 & 17.5 & 23.93 & 29.78 & 26.85 & 74.75 & 93.09 & 83.92 \\
\hline Mean & 5.66 & 7.33 & & 14.33 & 17.33 & & 19.01 & 24.92 & & 62.55 & 81.73 & \\
\hline \multicolumn{13}{|l|}{$\operatorname{SEm} \pm$} \\
\hline $\mathrm{S}$ & & 0.273 & & & 0.608 & & & 0.393 & & & 0.58 & \\
\hline V & & 0.223 & & & 0.495 & & & 0.32 & & & 0.475 & \\
\hline $\mathrm{S} \times \mathrm{V}$ & & 0.387 & & & 0.86 & & & 0.556 & & & 0.826 & \\
\hline \multicolumn{13}{|c|}{$\mathrm{CD}(p=0.05)$} \\
\hline S & & 0.862 & & & 1.91 & & & 1.24 & & & 1.82 & \\
\hline V & & 0.704 & & & 1.56 & & & 1.01 & & & 1.50 & \\
\hline $\mathrm{S} \times \mathrm{V}$ & & 1.22 & & & 2.921 & & & 1.754 & & & 2.6 & \\
\hline
\end{tabular}




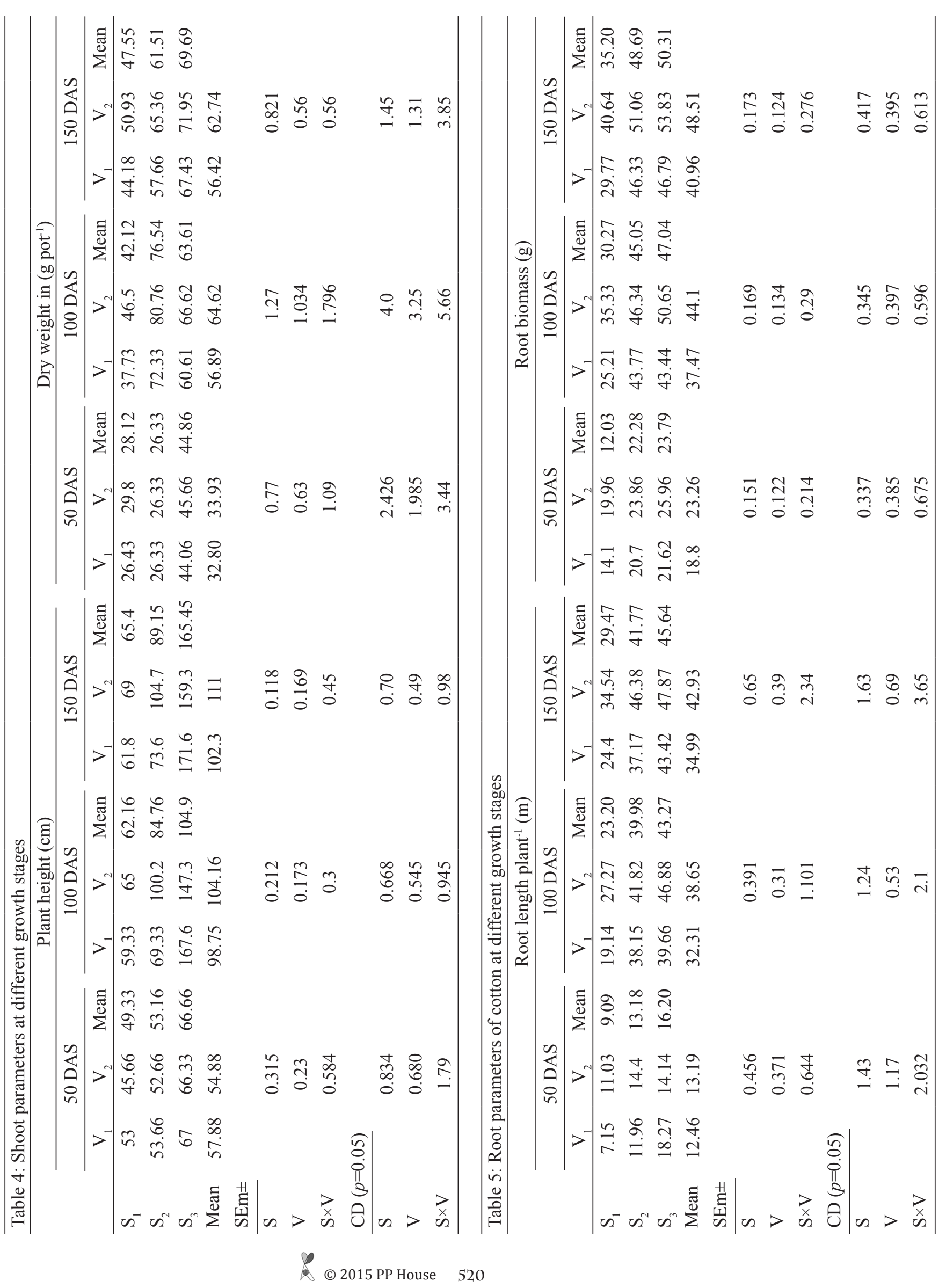


stage, alluvial soil produced higher biomass compared to black and red soil. Similar improvement in yield attributes and seed cotton yield due to insecticidal pest management was reported earlier by (Bhosale et al., 2004).

\section{Conclusion}

There were hardly any significant differences in essential ecosystem functions such as AM fungi infection and yield attributes among $\mathrm{Bt}$ and non-Bt isoline at any stages of crop growth as well as after harvest. Results of the present study did not provide any firm evidence so that we can conclude both $\mathrm{Bt}$ and non-Bt cotton cultivars were equally capable of establishing mycorrhizal symbiosis.

\section{Acknowledgement}

We hereby acknowledge the financial support extended by the Department of Soil Science and Agricultural Chemistry, Banaras Hindu University for conducting the study.

\section{References}

Benedict, J.H., Ring, 2004. Transgenic crops expressing Bt proteins:current status, challenges and outlook, Transgenic Crop Protection: Concepts and Strategies. Science Publishers, 15-83.

Beura, K., Rakshit, K., 2011. Effect of Bt cotton on nutrient dynamics under varied soil type. Italian Journal of Agronomy 6(4), 25-28.

Bhosale, B.B., Patange, N.R., Rathod, K.S., 2004. Insecticidal management of key pest in Bt cotton. In: Proceeding International Symposium on Strategies for Sustainable Cotton Production-A global vision.3. Crop Protection 158-160.

Bierman, B., Linderman, R., 1981. Quantifying vesiculararbuscular mycorrhizae: proposed method towards standardization. New Phytology 87, 63-67.

Blanche, S.B., Myers, G.O., Zumba, J.Z., Caldwell, D., Hayes, J., 2006. Stability comparisons between conventional and near-isogenic transgenic cotton cultivars. Journal of Cotton Science 10, 17-28.

Bouyoucos, G.J., 1962. Hydrometer method improved for making particle size analysis of soils. Agronomy Journal 54, 464 .

Bray, R.H., Kurtz., L.T., 1945. Determination of total, organic and available forms of phosphorus in soils. Soil Science 64, 101-109.

Castaldini, F.F., Santomassimo, M., Candilo, Di Miclaus, N., 2005. Impact of Bt corn on rhizospheric and soil eubacterial communities and on beneficial mycorrhizal symbiosis in experimental microcosms. Applied Environmental Microbiology 71, 6719-6729.
Dong, H., Li, W.J., Tang, W., Li, Z.H., Zhang, D.M., 2006. Effects of genotypes and plant density on yield, yield components and photosynthesis in Bt transgenic cotton. Journal of Agronomy and Crop Science 192, 132-139.

Dong, H.Z., Li, W.J., 2007. Variability of endotoxin expression in Bt transgenic cotton. Journal of Agronomy and Crop Science 193, 21-29.

Dunfield, K.E., Germida, J.J., 2004. Impact of genetically modified crops on soil-and plant-associated microbial communities. Journal of Environmental Quality 33(3), 806-815.

Glandorf, P.A.H.M., Bakker, VanLoon, L.C., 1997. Influence of the production of antibacterial and antifungal proteins by transgenic plants on the saprophytic soil microflora. Acta Botanica Netherland 46, 85-104.

Griffiths, B.S., Caul, S., Thompson, J., Birch, A.N.E., Scrimgeour, C., Cortet, J., Foggo, A., Hackett, C.A., Krogh, P.H., 2006. Soil microbial and faunal community responses to Bt maize and insecticide in two soils. Journal of Environmental Quality 35, 734-741.

Halemani, H.L., Hallikeri, S.S., Nandagavi, R.A., Nooli, S.S., 2004. Performance of Bt hybrids at different levels of fertilizers under protective irrigation. In: Proc. International Symposium on Strategies for Sustainable Cotton Production-A Global Vision, 2. Crop production, 139-141.

Hallikeri, S.S., Halemani, H.L., Nandagavi, R.A., Nooli, S.A., 2004. Response of Mahyco Bt cotton hybrids to levels of fertilizers under protective irrigation. In: Proc. International Symposium on Strategies for Sustainable Cotton Production- A Global Vision. 2. Crop Production, 139-141.

Hanway, J.J., Heidel, H., 1952. Soil analysis methods as used in Iowa State College Soil Testing Laboratory. Bulletin 57, Iowa State College of Agriculture, Iowa, USA, 131.

Hebbar, K.B., Perumal, N.K., Khadi, B.M., 2007. Photosynthesis and plant growth response of transgenic Bt cotton (Gossypium hirsutum L.) hybrid under field condition, Photosynthetica 45, 254-258.

Jackson, M.L., 1973. Soil Chemical Analysis, Indian Reprint, Prentice-Hall of India Pvt. Ltd. New Delhi, India.

James, C., 2006. Executive Summary of Global Status of Commercialized Biotech GM Crops. ISAAA Briefs, 35.

James, C., 2013. Global Status of Commercialized Biotech/ GM Crops: 2013. ISAAA Brief No. 46. ISAAA: Ithaca, New York.

Lindsay, W.L., Norvell, W.A., 1978. Development of a DTPA soil test for Zinc, iron, manganese and copper. Soil Science Society of America Journal 42, 421-428.

Motavalli, P.P., Kremer, R.J., Fang, M., Means, N.E., 2004. Impact of genetically modified crops and their 
management on soil microbially mediated plant nutrient transformations. Journal of Environment Quality 33, 816-824.

O'Callaghan, M., Travis, R.G., Burgess, E.P.J., Malone, L.A., 2005. Effects of plants genetically modified for insect resistance on nontarget organisms, Annual Review of Entomology 50, 271-292.

Olsen, S.R., Cole, C.V., Watanable, F.S., Dean, L.A., 1954. Estimation of available phosphorus on soil by extraction with sodium bicarbonate. U.S.D.A. Circular.

Patra, A.K., Abbadie, L., Clays-Josserand, A., Degrange, V., Grayston, S.J., Guillaumaud, N., Loiseau, P., Louault, F., Mahmood, S., Nazaret, S., Philippot, L., Poly, F., Prosser, J.I., Le Roux, X., 2006. Effects of management regime and plant species on the enzyme activity and genetic structure of $\mathrm{N}$-fixing, denitrifying and nitrifying bacterial communities in grassland soils. Environmental Microbiology 8, 1005-1016.

Powell, E., 2007. Mycorrhizal and rhizobial colonization of genetically modified and conventional soybeans. Applied Environmental Microbiology 73, 4365-4367.

Prakash, A.H., Bandopadhyay, K.K., Gopalkrishan, N., 2008. Growth and biomass partitioning in Bt and NBt cotton hybrids in winter irrigated irrigated situation in southern zone of india. Journal of Indian Society of Cotton Improvement 129-142.
Srinivasulu, K., Hema, K., Prasad, N.V.V.S.D., Krishana Rao, K.V., 2006. Performance of cotton hybrids under different spacing and nitrogen levels in black cotton soils of coastal Andhra Pradesh. Journal of Cotton Research Development 20, 99-101.

Stotzky, G., 2004. Persistence and biological activity in the soil of the insecticidal proteins from Bacillus thuringiensis, especially from transgenic plants. Plant and Soil 266, 77-89.

Subbiah, B.V., Asija, G.L., 1956. A rapid procedure for assessment of available nitrogen in soils. Current Science 31, 159-160.

Turrini, A., Sbrana, C., Nuti, M.P., Pietrangeli, B., Giovannetti, M., 2004. Development of a model system to assess the impact of genetically modified corn and aubergine plants on arbuscular mycorrhizal fungi. Plant and Soil 266, 69-75.

Walkley, A., Black, C.A., 1934. An examination of the Degtjareff method for determining soil organic matter and a proposed modification of the chromic acid titration method. Soil Science 37, 29-38.

Wei, X.D., Zou, H.L., Chu, L.M., Liao, B., Ye, C.M., Lan, C.Y., 2006. Fields released transgenic papaya affects microbial communities and enzyme communities and enzymes activities in soil. Plant and Soil 285, 347-358. 